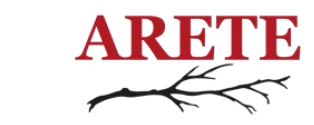

Politik Felsefe Dergisi

Journal of Political Philosophy

\title{
Jacques Rancière'in Politik Düşüncesinin Günümüzdeki Anlamı (Oliver Davis ile Söyleşi)
}

\author{
Oliver DAVIS* \\ Zeliha DİsCi***
}

Rancière'in politik düşüncesinin günümüzdeki anlamı nedir? Bu soruyu yanıtlamak üzere Warwick Üniversitesi, Fransız Çalışmaları bölümünde çalışan ve Rancière hakkındaki çalışmalarıla tanınan Oliver Davis ile bir röportaj yaptık.

Zeliha Dişci (ZD): Rancière'in düşüncesinden baktığımızda 2000'lerden beri yaşadığımız toplumsal hareketleri siyasal açıdan nasıl yorumlamalıyız? Zira Rancière’e

* Prof. Dr. I Prof.

Fransız Çalışmaları Bölümü, Modern Diller ve Kültürler Okulu, Warvick Üniversitesi I French Studies, School of Modern Languages and Cultures, Warvick University.

${ }^{* *}$ Dr. Öğr. Üyesi I Assist. Prof.

Siyaset Bilimi ve Kamu Yönetimi Bölümü, Kafkas Üniversitesi I Political Science and Public Administration Department, Kafkas University.

zeliha.disci@gmail.com

Orcid Id: 0000-0001-5650-680X

Doi: http://dx.doi.org/10.47614/arete.pfd.43

Davis, O. / Dişci, Z. (2021). Jacques Rancière'in Politik Düşüncesinin Günümüzdeki Anlamı (Oliver Davis ile Söyleşi). Arete Politik Felsefe Dergisi. 1(2). 92-99. 
yöneltilen en önemli eleştirilerden biri, bir siyasal deneyimde asıl odaklandığ ile politikanın karşılaşması, yanı uyuşmazlık olduğu, fakat yaşamın uyuşmazlık sonrasında nasıl düzenleneceğine ilişkin bir tahayyülünün bulunmadığı yönündedir.

Oliver Davis (OD): Jacques Rancière adına konuşamam elbette ama başka alanlara geçmeden önce, yıllarca onun eserleri hakkında düşünmüş biri olarak sorularınıza yanıt verebilirim. Öncelikle bu röportaj benim için iyi bir zamanda geldi, çünkü son zamanlarda onun düşüncesi, bu düşünceye verdiğim anlam ve onun bana kattıkları üzerine düşünmek amacıyla diğer çalışmalarıma ara vermiştim. Sorunuzun sonundan başlarsak eğer, politikanın düşünürü olarak Rancière'in tahayyülünü kesinlikle uzun vadeli örgütlenmeye, yani deyim yerindeyse polis, yönetim veya hükümet biçimi olarak "politikaya" [policy] yönlendirmeyi seçmediği görüşüne katılıyorum. Düşüncesi organizasyon veyahut yönetim tarafında değil. Sorunuzun ima ettiği gibi, bunu bir eleştiri veya zayıflık olarak görmeyi seçebilirsiniz. Yine de felsefenin başlangıcından itibaren yönetsel veya örgütsel olanın felsefeye musallat olma şekli, felsefenin her zaman teknokratik düzenlemeye doğru devrilme noktasında olduğu yol hakkında düşünmeye değer olduğunu söyleyebilirim. Eleştirel bir perspektiften bakıldığında, felsefenin hukukiliği [juridicism] -burjuva devlet örgütlenmesinin hukuksal biçimleriyle iç içe geçişi- açık bir sorun, fakat bir bakıma, belki de en açık biçimde Kant ve Hegel'de olan hukuksal olanla bu sorunlu örtüşme yönetsel olanla daha az izlenebilir iç içe geçişi maskeler. Rancière naif, kesinti anını fetişleştiren, hatta şeylerin başlangıçlarına ve ortaya çıkışlarına meyilli bir çocuk veya "sorumsuz" biri olarak, şeylerin başlangıçlarının veya ortaya çıkışlarının kaydının daha "olgun” yükünü omuzlamayı tahayyül etmeye isteksiz olarak görülebilir, ama bu tarz eleştiriler felsefenin teknokratik cazibesinin bütün boyutunu kabul etme konusundaki isteksizliklerini ele verir. 2000'li yıllardan itibaren yaşadığımız toplumsal hareketler hakkında sorduğunuz soru ilk olarak oldukça geniş ve heterojen bir dizidir ve kuşkusuz bu deneyimlerin konusudur. Bildiğiniz gibi, 1989'da Berlin Duvarı yıkıldığında sağcı ideologlar muzaffer bir şekilde “Tarihin Sonu”nu ve yeni, pürüzsüz bir mutabakata dayalı küresel düzenin ortaya çıktığını ilan ettiler. Rancière, bu muzafferliğin içi boş yüzünü sezmekte ve bu yeni çağın uzlaşmacılığını belirleyip eleştirmekte çabuk davrandı. Ben bu çağa, Wendy Brown'un (2018) kullandı̆̆ 1 eleştirel anlamla, "yönetişim" [governance] diyeceğim ve ona bir şekilde borçlu olmaksızın Rancière'in çalışmasını yansıtan Brown'un eleştirisi aynı terimi kesinlikle 
yeniden konuşlandırmak için oldukça güçlüdür. Bu terim, yalnızca küresel jeopolitiğin daha yüksek zirvelerinde değil, aynı zamanda STK'lardan üniversitelere ve vahşi yaşam parklarına kadar hemen her örgütsel varlıkta ortaya çıkar ve bu düzenin kendini tanımlama eylemlerinde sıklıkla kullanılır. "Yönetişim" [governance] terimiyle tanımladığım bu yeni çağ neoliberal kapitalizmin geniş kapsamlı uygulamalarının yeterince tanınmayan yönetsel düzenleyici uygulamalarının sosyal ve siyasal dünyamızı yeniden şekillendirdiği, demokratik tartışmanın ufkunda açıkça beliren ya da bir sorun olarak inşa edilen "termit benzeri" yeniden örgütleme eylemlerinin büyük ölçüde olmadığı bir çağdır (Brown, 2018). Başka bir deyişle, bu işleyişin çoğu idari, örgütsel, teknik -eskiden ‘bürokratik’ olarak adlandırılan- şekillerde üstlenilmişti, fakat kümülatif etkileri daha yeni yeni kavriyoruz.

ZD: Polis, siyaset felsefesi açısından büyük bir öneme sahip olan, antik Yunan'dan günümüze gelen bir kavramdır. Farklı kullanım biçimleri olmasına rağmen Rancière ile birlikte yeniden siyasal tartışmaların odağı haline geldiğini görüyoruz. Polis kavramını değerlendirmesi açısından Rancière'in bir fark yarattığını düşünüyor musunuz?

OD: Açık bir şekilde kasten primitif veya primitif olmayan bir işlemci, -başka bir deyişle, siyasal bir teknoloji- olarak homojen 'yönetişim' [governance] ve 'konsensus' düzenini bölmek için tasarlanmış, belki de en iyi ikili teknikleri açısından anlaşılabilecek polis ve siyaset arasındaki karşıtlıktan ayrı olarak, Rancière'i genel anlamda bir polis düşünürü olarak görmüyorum ve belki de bu bir sorundur. Geniş anlamıyla Yunan'dan türetilmiş sosyal düzenleme ve bununla bağlantılı sosyal örgütlenmenin bir formu olarak 'polis bilimi' anlamında polisin tarihine ilişkin mükemmel eleştirel açıklamalar var: Rancière'in çalışmasıyla birlikte verimli bir şekilde okunabilen ve aynı zamanda onu aydınlatmaya yardımcı olduğunu düşündüğüm Mark Neocleous’un Toplumsal Düzenin Inşası: Polis Erkinin Eleştirel Teorisi'ni (2016) bu noktada hatırlayabiliriz. Fakat Rancière'in kendisi henüz bariz bir şekilde bu tür bir analitik siyasi tarih yapmakla ilgilenmiyor. Siyasal çalışmasının en çok faydalandığı takviye edici yer, bugün neoliberal kapitalizmin makinesel yönetişim bürokrasilerinin gerçekte işleme şekline dair, örneğin burada, orada ve her yerde var olan mikro-eşitsizlikleri örneklendirici, hiyerarşize edici, yani, tasnifleyici, algoritmik- yönlendirilen operasyonların bizi kuşatan dünyayı yeniden düzenleme yoluna dair ayrıntılı teknik anlayıştır diyebilirim. Bununla birlikte, bu kavrayışa bugün bürokrasinin aldığı formların kavramsal ve pratik kavranışı üzerinden 
erişilebilir -ve burada David Graeber'in geç dönem çalışmalarını, özellikle de Kuralların Ütopyast (2013) isimli eserini tavsiye edebilirim.

ZD: Gilles Deleuze ile ilgili temel yargılardan birisi Spinoza, Kant gibi düşünürleri bütünlüğü içinde ele almadığı, kendi felsefesi açısından araçsallaştırıp anlamından uzaklaştırdığg yönündedir. Benzer bir yargıyı Platon, Aristoteles ve Hobbes gibi siyaset felsefesinin oldukça önemli düşünürlerini kendi felsefesini kurarken kullanan Rancière açısından da söyleyebilir miyiz?

OD: Felsefe tarihindeki belirli figürlerin yeterince 'bütünlükleri' içinde ele alınıp alınmadıklarına dair kaygı bana tuhaf ve belirgin bir şekilde yönetimsel ve aslında felsefenin fiilen öğretildiği ve uygulandığı şekliyle yönetme eğilimini ifade ediyormuş gibi görünüyor. Kuşkusuz, Deleuze'ün çalışmalarında ve aynı zamanda Michel Foucault'nun, Rancière'in eserlerinde de hafifçe dokunan, ele geçirici, yeniden anlamlandırıcı ve kararlı bir şekilde kısmi olan okumalar hemen hemen beklenen şeylerdir. Fransız kıtası geleneği içinde Jacques Derrida bu anlamda zit bir figürdür: Külliyatının tamamı genel olarak hala önemli ve okumaları, ilgili eserin unsurlarını seçme yolları yönetsel olmaktan başka bir şey değilmiş gibi görünse de, sıklıkla eserin bütün yapısına yayılır. Bugün, her son eskiz ve notun izini sürme ve envanterini çıkarma arzusunda özünde antikacı olan çok fazla bilim var - bunların bir kısmı ne yazık ki finanse edilen ve tanınan beşerî bilimlerdeki temel araştırma yöntemiyle yetinmek durumundadır- ve bu şartlarda az önce bahsedilen filozofların yaklaşımları bana özellikle hatalı gibi geliyor.

ZD: "The Anti-Police of Mai '68 Fifty Years On” (2018) isimli çalışmanızda kullandığınız "anti-police" kavramıyla Rancière'in politika kavramına bir yorum getirdiğinizi söyleyebilir miyiz? Zira Rancière'de politika, polisin içinde beliren fakat polis etkinlikleri diyebileceğimiz sayım şekillerini tartışmaya açan etkinliklerle anlamını bulur.

OD: Evet ve hayır: O özel sayıyı ya da ona yazdığım makaleyi gerçekten Rancièrci terimlerle sunmadım. Makalem öncelikle tarihsel ve Rancière'den uzaklaştıktan sonra ürettiğim bir çalışma alanına aittir. Yine de özel sayı için bu özel odağa odaklandığımda, kesinlikle Rancière'in 1968 Mayısını ve belki de daha özel olarak Kristin Ross’un açık bir şekilde Rancièrci 'olaylar' kavrayışından ve özellikle de belirli tarihsel uygulama 
türleriyle polislik uygulamaları olarak tarihsel açıdan yetkilendirilmiş anlaşılırlık formlarına dair tartışmasından etkilendim. '68 Mayısının tarihine bakarken, olaylar hakkındaki ilk araştırmaların kimilerinin olaylar hali hazırda vuku bulurken ve aktivistaraştırmacıların polis vahşetine ilişkin soruşturmaların şeklini almasını ironik buldum. Aradan geçen yıllarda - ve eminim ki o zamandan beri geçen yarım yüzyılda o moment hakkında çok şey yazıldığını biliyorsunuzdur - polis ve protestocuların 'anti-polis' kavram ve uygulaması büyük ölçüde başka kaygıların gölgesinde kaldı. Bununla birlikte, makalem, muhtemelen şu anda ifade ettiğimden çok daha tarihsel ve beni polis arşivlerine bile götürmüştür. Esas olarak burada keşfettiğim şey, tarihçilerin göstericilere karş1 seferber edilen polis güçlerinin tam kapsamını - İngilizce-konuşanların basitçe 'polis' deme eğiliminde oldukları, Fransızların ise değişik farklı özel kurumsal birimleri yerinde bir şekilde ifade ederken söylediği gibi les forces de l'ordre dedikleri- ve özellikle de SAC (de Gaulcu bir siyasi örgüt) ile bağlantılı, muhtemelen Jacques Foccart tarafından yönetilen sağ-kanat ve aşırı-sağ milislerin sivil giyimli komando birliklerinin önemli rolünü görmedeki başarısızlıklarıdır. Bunlar, esasen, bir kontrgerilla operasyonu olarak nitelendirilebilecek olan polisin yanında gizlice konuşlandırılan şok birlikleriydi. Ne var ki, yaklaşımım Critical Security Studies tarafından geliştirilen 'güven(siz)lik' hakkındaki düşünceye Rancière'den daha fazla şey borçludur.

ZD: Rancière'in politika ve politik olan hakkındaki düşüncelerini çağdaş Fransız düşüncesi içinde nerede konumlandırıyorsunuz? Bu soruyu soruyorum, çünkü siyaseti kesintiye uğratıcı etkinliklerle birlikte düşündüğümüzde, kesintiye uğratma motifi yirminci yüzyıldan günümüze çağdaş Fransız düşünürlerde çok sık karşımıza çıkar.

OD: Beni çağdaş Fransız düşüncesinde yürütmeye davet ediyor göründüğünüz sınıflandırıcı araştırma türünün çekiciliğini anlamayı korkarım ki bıraktım. 'Kesinti'nin gerçekten bir 'motif' olduğundan emin değilim; daha ziyade, geniş bir yelpazedeki tikel kaygılardan ve yerleşik sorgulamalardan oldukça yüksek düzeyde bir soyutlama. Elbette ki 'günümüzde Fransız düşüncesi' içindeki benzerliklerden bahsedilebilir, ancak bu söyleşide daha önce yaptı̆̆ım yorumlardan da çıkarılabileceği üzere, Rancière’i daha fazla farklı ulusal-kültürel konumlardan, örneğin Wendy Brown veya David Graeber gibi radikal siyaset düşünürleriyle birlikte okumaya eğilimliyim. Dahası, Rancière'in düşüncesinin gelişimine tarihsel olarak baktığınızda, İngiliz tarihçi Edward P. Thompson ile teması açık bir şekilde çok önemliydi ve Rancière onu her zaman geniş çapta ve 
beklenmedik bir şekilde okumuştu (The Method of Equality'deki (2016a) Gauny ile karşılaşmasının onun için Lacan veya Heidegger'i okumaktan daha önemli olduğu konusundaki açıklamayı hatırlıyorum). Ben olsam onu kişisel olarak Fransız solunun çağdaş düşüncesinin sınırları içine yeniden dahil etmeye çalışmazdım, her ne kadar bu konuda iyi iş çıkaran pek çok iyi kitap olsa da.

ZD: Cahil Hoca'daki (2016b) zekaların eşitliğine dair söylemi modern eşitlik anlayışının geliştirilmiş bir versiyonu olarak görebilir miyiz? Bu konuda Rancière'in Peter Hallward tarafından eleştirildiğini hatırlıyorum. Hallward'a göre (2005) Rancière “tekil olanın evrensel olana tutunduğu eşitlik anlayışını yeterince somutlaştırmaz.” Bu da eşitlik anlayışının hala mistik seviyede kaldığı anlamına gelir sanırım...

OD: Bu, önceki sorunuzdan oldukça net bir şekilde çıkar: Rancière, örneğin Alain Badiou gibi -kuşaksal, biyografik ve kurumsal açıdan- onun doğal olarak komparatörü olan düşünürlerle karşılaştırılmaya çalışılırsa, bu türden bir hüküm hemen belirir. Bir filozof ve yorumcu olarak Peter'e büyük bir saygım var, ancak Rancière hakkındaki bu hükmün onun Badiou olmadığına itiraz etmek anlamına geldiğini, diğer yandan her iki felsefi projenin tekilliğinin göz ardı edilmesini içerdiğini öne sürüyorum. Üstelik, evrensel, Uyuşmazlık'ta (2006) özetlenen özgürleşme tekniklerinin bir boyutudur; Rancière'in evrenseli göz ardı ettiğini öne sürmek doğru değil, fakat onunki Badiou'nun sıkça yaptığı gibi evrensel adına konuşan bir yapıt da değil. Ne de tam tersine, isimsiz birçok yorumcunun iddia ettiği gibi, ABD siyasal-kimlik 'aktivizmi'nin sonsuz tikelciliği içinde doğru bir şekilde kapsanabilir.

ZD: Yaklaşık iki yıldır covid-19 salgınını yaşıyoruz. Farklı düşünürler virüse, virüs karşısında devlet etkinliklerine ve varlığımızı nasıl kurup güçlendirmemiz gerektiğine dair yazılar yazıyor. Kendisini bir filozof olarak tanımlayan Rancière' de ise bir suskunluk görüyoruz. Yaşadığımız bu dönem hakkında Rancière'in suskunluğuyla ilgili ne düşünüyorsunuz?

OD: Rancière'in çağdaş toplum hakkındaki ‘sessizliği’nden söz etmek pek doğru olmaz. Amerikan Kongre Binası fırtınası ve onu analiz etmek için yetersiz kalan girişimler hakkında kısa ama çok anlamlı polemik makalesini gördünüz mü? ${ }^{1}$ Fakat şu

\footnotetext{
${ }^{1}$ Makale için: https://www.versobooks.com/blogs/4980-the-fools-and-the-wise
} 
anda yayınlanmış çalışmasının, estetiğin politik tarihine, çağdaş siyasetin olaylarından daha fazla özen gösterdiği konusunda sizinle aynı fikirdeyim. Yine de, bir şekilde her şey hakkında, Sartercı angaje olmuş bir entellektüelin ya da çağdaş bir yorumcunun bir zamanlar yaptığı gibi, konuşması gerektiğini varsaymamız yanlış olur diye düşünüyorum. $\mathrm{Bu}$ günlerde radyo dalgaları, güncel olaylar hakkında 'uzman' yorumlarını sunan akademisyenlerle dolu; ama, Rancière'in düşüncesi, bildiğiniz gibi, açıklayıcı uzmanlığın temel bir sorgulamasını içerir. Çağdaş güncel olayların epifenomeni ile ilgili ihtiyatlılığı bu yaklaşımla tutarlı görünüyor.

Devam eden salgına yanıt olarak dünya çapında hükümetler tarafından alınan halk sağlığını koruma önlemleri ile ilgili olarak, bu halk sağlığı önlemlerine yönelik her şeyden önce gelen biyomedikal ihtiyacın aynı zamanda baskıcı rejimler için bir fırsat olduğu açıktır. $\mathrm{Bu}$ önlemlere ilişkin görüşümüz, örneğin, Foucault'nun Hapishanenin Doğuşu'ndaki (2015) veba sınırlama protokolleri tartışmasıyla değiştirilebilir, ancak muhtemelen, Çin'de ilk uygulamadan bu yana gerçekte ne yapıldığına bakarak bu tür önlemlerin nereye yönelebileceğini de görebiliriz. Bir cep telefonu uygulamasının artık bireyleri virüs riskine göre renkle kodladığı, hareketlerini takip ettiği ve kamusal alan ve kaynaklara erişim izni vermek veya reddetmek için kullanıldığı bir salgın bu. Burada "aşı pasaportları' gibi viral kontrol önlemlerinin savunucuları karşılaştırmaya şiddetle karşı koysalar da, bunların politik olarak ima ettiği şey, Çin'de halihazırda yaygın olarak kabul edilen radikal olarak eşitsiz iç yönetim teknolojilerinden farklı değil. Benim görüşüme göre, insanların Rancière'in her önemli konu hakkında düşünmüş ve konuşmuş olması gerektiğini hayal etmeyi bırakmalarının ve çalışmalarını kendi özerk araştırmalarında kullanmaya başlamalarının zamanı geldi. Bunu, Tim Dean'le birlikte, gelecek Nisan ayında çıkacak olan Hatred of Sex isimli kitapta yapmaya çalıştık. Orada Rancière'in Demokrasi Nefreti'ndeki argümanını, cinsiyete dair çağdaş isteksizlik ve özellikle de yönetişim bürokrasilerinin cinsel 'uygunsuzluğu' bir yönetim, polislik biçimi olarak nasıl kullandığı hakkında konuşmak üzere uyarlıyoruz. Ama aynı zamanda çalışmasını, her ikisi de bir dereceye kadar çalışmasının özüne aykırı gelişmeler olan psikanaliz (özellikle Jean Laplanche) ve queer teori ile diyaloğa sokuyoruz.

\section{Kaynaklar}

Brown, W. (2018). Halkın Çözülüşü: Neoliberalizmin Sinsi Devrimi. Barış Engin Aksoy (Çev.). İstanbul: Metis. 
Davis, O. (2018). "The anti-police of Mai '68 fifty years on" Modern and Contemporary France. 26(2). pp. 107-114.

Davis, O. / Dean, T. (2022). Hatred of Sex (Provocations). Lincoln: University of Nebraska Press.

Foucault, M. (2015). Hapishanenin Doğuşu. Mehmet Ali Kılıçbay (Çev.). Ankara: İmge. Graeber, D. (2016). Kuralların Ütopyası. Muammer Pehlivan (Çev.). İstanbul: Everest.

Hallward, P. (2005). "Jacques Ranciere: The Subversion of Mastery" Paragraph, No:28, pp. 26-45.

Neocleous, M. (2013). Toplumsal Düzenin İnşast: Polis Erkinin Eleştirel Teorisi. Ahmet Bekmen (Çev.). İstanbul: H2O Yayınları.

Rancière, J. (2006). Uyuşmazlık. Hakkı Hünler (Çev.). İzmir: Ara-lık.

Rancière, J. (2016a). The Method of Equality (Interviews with Laurent Jeanpierre and Dork Zabunyan). Julie Rose (Çev.). Cambridge: Polity Press.

Rancière, J. (2016b). Cahil Hoca: Zihinsel Özgürleşme Üstüne Beş Ders. Müge Gürsoy Sökmen (Çev.). İstanbul: Metis.

Rancière, J. (2020). Demokrasi Nefreti. Utku Özmakas (Çev.). İstanbul: İletişim. 